\title{
The Moroccan Monarchy and the Islam-oriented PJD: Pragmatic Cohabitation and the Need for Islamic Political Secularism
}

\author{
Abdellatif Hissouf \\ Walden University
}

\begin{abstract}
This paper aims to analyze the political relationship between the Moroccan monarchy and the moderate Islam-oriented Party of Justice and Development (PJD), which has been in power since 2011. The research methodology involves an in-depth case analysis and relies on a substantial number of primary and secondary sources such as official speeches, official political statements, journal articles and newspapers. The study finds the relationship between the PJD and the monarchy inconsistent, similar to the PJD's relationship with other political parties. The paper argues that adopting an approach based on an Islamic political secularism that considers Morocco's specific political realities may ease tension between the PJD on the one hand and the monarchy and other parties on the other.
\end{abstract}

Keywords: Islamic secularism, political Islam, Moroccan politics, Party of Justice and Development (Morocco), King Mohammed VI, Abdelilah Benkirane, Makhzen

\section{Introduction}

The moderate Islam-oriented Party of Justice and Development (PJD), which won the 2011 Moroccan elections, leads Morocco's coalition government. However, due to ideological conflicts with political parties in opposition and within the coalition, the PJD works in a difficult political environment. Further, some believe that behind the scenes, the Makhzen ${ }^{1}$ has been attempting to weaken the PJD's popularity. In fact, although the party rode the wave of the Arab Spring to power, "the Makhzen still sees the PJD as a temporary appendage to the stability of the system."2

The success or failure of the PJD is of crucial importance, as it is one of the few cases in the Middle East where an Islamic party has achieved power through a consensual political agreement and without violent uprisings. It is also the only Islamist government in the Arab world since the ousting of Muslim Brotherhood-affiliated President Morsi in Egypt and the loss of popularity of the Ennahda group in Tunisia. Thus, the nature and quality of the relationship between Morocco's monarchy and other political actors on the one hand and the moderate Islam-oriented PJD on the other deserves high attention in an unstable region. In this regard, a consensual policy based on a type of Islamic political secularism that respects

Abdellatif Hissouf, PhD, Public Policy and Administration, Walden University. Email: abdellatif_hissouf@yahoo.com.

1 The Makhzen (the deep State, literally storehouse), represents an informal alliance among the monarch, his advisers, selected businessmen, high-ranking bureaucrats, the security system (military and police), and loyalist tribal chiefs.

2 Anouar Boukhars, "Morocco's Islamists: Bucking the trend?” FRIDE Policy Brief No. 182, June 2014, 4, http://fride.org/ download/PB_182_Morocco_Islamists.pdf. 
Morocco's existing political realities may narrow divergences, create trust among all political actors, and open the door to Islamic interpretations that answer the needs of a growing, modern Moroccan society.

The next section analyzes the Moroccan political system and discusses the king's central political and religious role. The following sections deal with the PJD's gradual integration into the Moroccan electoral system, the pragmatic cohabitation between the monarchy and the PJD, the king's control and criticism of the PJD and the challenges that the PJD faces. The last section focuses on the need for an Islamic political secularism that considers Morocco's unique political realities. This article thus aims to analyze the political relationship between the Moroccan monarchy and the moderate Islam-oriented PJD and discuss the best approach to surmount challenges.

\section{The Moroccan Political System}

\subsection{Political integration}

Since its independence in 1956, Morocco has been governed by a semi-authoritarian regime, willing to share power long as it keeps overall control. In 1959, the Union Nationale des Forces Populaires (UNFP), later called the Union Socialiste des Forces Populaires (USFP), broke away from the Istiqlal party and began to vehemently oppose the monarchy. For many years, Istiqlal and the USFP united to fight a new constitutional amendment that sought to give the monarchy more power. Prior to the 1997 parliamentary elections, Morocco's political scene had become dramatically fragmented, and dominated by pro-regime parties (also called administrative parties). Between 1970 and 1990, the monarchy helped create regime-loyal parties such as the Mouvement Populaire (MP), the Rassemblement National des Indépendants (RNI), the Union Constitutionnelle (UC), and the Partie Démocratique Nationale (PDN). Nonetheless, the country's political arena has continued to include strong national parties, such as Istiqlal, the USFP, the Party of Progress and Socialism (PPS), and lately, the moderate Islam-oriented PJD, which formed in the mid-1990s.

Following the 1993 election, pro-monarchy parties (called the Wifaq (pro-government right) and composed of the UC, the MP, and the PDN) formed the government. Then, in an attempt to include the opposition (called the Koutla (opposition coalition) and composed of the USFP, the Istiqlal, and the PPS), King Hassan II suggested building a consensual coalition government. The Koutla initially rejected this arrangement because the king insisted on continuing to control Morocco's four most important ministries (Army, Justice, Religion and Interior), but in 1997, Abderahman Al-Yousfi, leader of the USFP, agreed. At that time, the USFP was considered "the most important political party in Morocco's 'democratic' movement,"3 and the arrangement was considered meaningful political reform that would provide an opportunity to challenge the monarchy's hegemony. ${ }^{4}$ However, although King Hassan II's opening up of the political system allowed socialists to become more integrated into Moroccan politics, it also helped to weaken their challenge to the monarchy's absolute power.

Once in government, the USFP and its Koutla allies promised to tackle Morocco's

3 James N. Sater, "Parliamentary elections and authoritarian rule in Morocco," Middle East Journal 63, no. 3 (2009): 382.

4 Mohamed Daadaoui, "Rituals of power and political parties in Morocco: Limited elections as positional strategies," Middle 
socioeconomic issues, to enhance democracy, and establish a state of law and human rights. Morocco is an emerging country, where all rights need to be promoted (employment conditions, women's rights, democracy, etc.). However, the government did not resolve the country's socio-economic problems (citizens' biggest concern) and Moroccans' disillusionment grew.

In the 2002 elections, the socialist USFP won again by a small margin, but the king appointed technocrat Driss Jettou as prime minister. This choice was interpreted as a failing of the democratic process because the monarch did not choose a representative from the USFP; however, the constitution at the time allowed the king to choose the prime minister. In the end, the USFP agreed to participate in Jettou's government after the monarchy agreed to allow USFP politician Muhammad Bouzoubaa to lead the Justice Ministry, a post until then reserved for regime loyalists. In the 2007 election, the USFP lost 12 seats, down to 38 from its 50 in 2002, ending up fifth in the polls. This regression resulted in Mohamed El Yazghi resigning as USFP First Secretary due to internal pressure, which then raised the question of how and whether the USFP would participate in the new government. Party activists wanted to cross over to the opposition side but party elite wanted to join the coalition government. The latter prevailed. Following the November 2011 elections, the USFP remained fifth, with 39 seats in the House of Representatives. After several days of delays and internal discussions, the party decided not to join the PJD government, preferring to regain a credible position in opposition. As Monjib states: "The party has lost its traditional base- the urban electorate, unions, employees, and civil servants - and has increasingly been dominated by notables who are more political entrepreneurs than engaged citizens." ${ }^{5}$ And in fact, the USFP had shifted from its progressive ideology and modernist ideals to political conservatism and a hierarchical internal administration. These transformations, which had been encouraged by the Makhzen, resulted in political suicide.

In the following section, I discuss the principal content of the 2011 constitution, the king's central religious role, and the PJD's integration into the Moroccan political scene.

\subsection{The 2011 constitution}

Morocco is defined in its 1996 constitution as a "democratic, social and constitutional monarchy." However, Morocco better fits the model of an 'executive monarchy,' where power is concentrated in the hands of the political authorities surrounding the monarch. As Kristina Kausch states about Morocco, "[formal] democratic structures and institutions veil an informal shadow governance structure, commonly called the Makhzen..., a network of the palace and its clients that dictate the main lines of policy and act as a gatekeeper for any kind of political reform." Kausch adds that "royal counselors, loyal technocrats of the king's personal entourage, are the true decision makers in the ministries." However, in March 2011, King Mohammed VI announced that he had designated a committee to prepare a "comprehensive constitutional reform," in a referendum. In addition to strengthening human rights, political pluralism, and individual

5 Maâti Monjib, "The Democratization Process in Morocco: Progress, obstacles, and the impact of the Islamist-Secularist divide" (working paper 5, The Saban Center for Middle East Policy at the Brookings Institute, 2011), 15, http://www.brookings. edu/ /media/research/files/papers/2011/8/morocco\%20monjib/08_morocco_monjib.pdf.

6 Kristina Kausch, "The European Union and political reform in Morocco," Mediterranean Politics 14, no. 2 (2009): 168.

7 Kausch, "The European Union," 168.

8 Mohammed Alaoui, "Discours royal le 9 mars 2011," [March 9, 2011 Throne Speech] YouTube video, 13:48, March 9, 2011, https://www.youtube.com/watch?v=9pTJoUI3W8s. 
liberties, the monarch promised in his speech to the nation that the status of prime minister, "as head of an executive entity," would be enhanced as part of the coming constitutional reform. The content of the new constitution, particularly in terms of human rights and good governance, quickly won the support of Moroccans, who believed it represented a turning point in the country's history. The results of the referendum confirmed that trend: $98.50 \%$ of Moroccans voting in the referendum said "YES" to the new text.

The new constitution is based on several principles: ${ }^{10}$ (1) to guarantee the rule of law, human rights, and political freedoms; (2) to increase judicial independence; (3) to guarantee that the prime minister will be chosen from the party that wins the most seats in parliament; (4) to strengthen the role of political parties and civil society; (5) to enhance transparency and continue the fight against corruption; (6) to enhance good governance and the protection of individual freedoms and (7) to enshrine ethnic minorities' rights (e.g., Berbers' and Sahraouis').

Jean-Noël Ferrié (as cited in Hélène Sallon, 2011) sees in these initiatives proof of the monarchy's openness to the people's requests and a "synchrony between the demands of the protestors and commentators, and what the monarchy is ready to give up." ${ }^{11}$ Ferrié adds: "all these things were maturing and needed a trigger. Mohamed VI has used, in the best sense, the manifestations of 20 February to boost some projects that were blocked for several years and rework the political and legal framework of the country with what Moroccans are asking for." ${ }^{12}$ Nonetheless, the real challenge is "implementation [rather] than codification [because] several of these elements are already ostensibly in the constitution of 1996, including equality of citizens before the law (Art. 5), freedom of opinion and association (Art. 9), and judicial independence from the executive and legislative branches (Art. 80)." ${ }^{13}$ In this regard, Kausch states that

powers are distinguished in law and discourse, but in practice there is neither separation nor balance of powers, with the palace-led executive exerting [a] leading influence over the legislature and judiciary. Government and parliament [still] execute the will of the Makhzen rather than the will of the electorate..$^{14}$

\subsection{The monarchy's control of the religious field}

Morocco has always lived with an identity that combines traditional culture, religion, and modernity; religion and politics are barely separable. The sultan (king), surrounded by a defined group of religious scholars, is a spiritual leader who rules his country in the name of Allah (God) because he claims descendancy from the Prophet Mohammed. In 1962, Hassan II introduced the king's title Amir Almouminin (Commander of the Faithful) into the Moroccan constitution. The king of Morocco is then considered the guardian of an official and 'controlled' Moroccan Islamic model, a belief system based on a triptych of Maliki rites, Achaarite doctrines, and Sufism. As political analyst Mohammed Tozy ${ }^{15}$ notes, this doctrine

\footnotetext{
9 Alaoui, "Discours royal."

${ }^{10}$ Alexis Arieff, Morocco: Current issues (CRS Report No. RL21579) (Washington, DC: Congressional Research Service, 2013), 3-4, http://www.fas.org/sgp/crs/row/RS21579.pdf.

"Hélène Sallon, "Mohamed VI offre au Maroc une révolution tranquille," Le Monde, March 10, 2011.

12 Sallon, "Mohamed VI" (author's translation).

13 Arieff, Morocco: Current issues, 4.

${ }_{14}$ Kausch, "The European Union," 168.

15 "La restructuration du champ religieux marocain, entretien avec Mohamed Tozy," Infos Sezame, January 16, 2007, http://www.sezamemag.net/société/39-entretien-du-mois/333-La-restructuration-du-champ-religieux-marocain,-entretien-avec- 
is the spirit of a pragmatic Malekism, which is close to the concerns of Moroccans, rather than the dogmatic Islam of other Muslim countries. Moroccans also encourage Sufism and Maraboutism, of which the latter is an important Moroccan tradition; Tozy calls it the Islam of mediation. ${ }^{16}$ In fact, throughout history, Moroccans have encouraged a "Happy Islam," an Islam of joy and music (samaa). ${ }^{17}$

Between 1970 and 1980 instruments of religious policy gradually emerged through a number of reforms by the Ministry of Habous and Islamic affairs, such as the establishment of regional Ulema councils (religious scholars), the Higher Council of Ulema, the 1982 restructuring of the ministry, the 1984 regulation on mosque construction, and the creation of high positions in charge of religious affairs in the Ministry of the Interior. In short, a set of measures was taken to better control the religious field. ${ }^{18}$

These institutional reforms reflected the authorities' desire to frame and preserve Moroccans' valued religious identity. To control the multitude of political expressions in the name of religion and to protect unity of worship, King Mohammed VI reminded citizens in his July 30, 2004 throne speech that he has been the only one to reconcile the political and the religious in order to safeguard the sanctity of religion, which he stated must remain outside the influence of various social and political opinion groups.

These new policies resulted in an administrative restructuring on how religion is managed in Morocco. There was a strong push for a Moroccan Islam by organizing the religious field and pursuing the training of religious scholars inside and outside the country. This initiative was a quick response to the terrorist events that occurred in Morocco on May 16, 2003; the policy aimed to deal with Islamic extremism and terrorism. Moroccan Islam, generally considered modern, clearly rejects extreme Salafism, including Jihadism. ${ }^{19}$

Katherine Marshall considers Morocco's recent religious reform revolutionary, especially in relation to the Moudawana (the Family Code, which governs areas of family law such as marriage, divorce, inheritance and child custody). She also discusses the innovative Mourchidate program, where women provide religious instruction and counseling, especially to other women, in a variety of venues, including local mosques. Marshall notes that Morocco is giving "a new and vibrant meaning" to what we may consider "moderate Islam" 20 by including women in promoting the doctrine. Nonetheless, specialists such as Driss Maghraoui argue that the reform of the religious field "was not so much about raising fundamental questions about the sacred text, the nature of religiosity or about the place of religion in politics, but more about pragmatic and politically strategic factors." 21 In fact, "a more moderate Islam is being promoted to counter the rising power of Islamist groups and more importantly radicalism." 22 Maghraoui adds that "the reforms of the religious field [have] taken up a security dimension in the sense of a 'moral security' that guarantees a 'Moroccan moral order' and security as it relates to the state in its attempt to counter Wahabism, Shia and radical Islamist groups."${ }^{23}$

Even with this arsenal of measures, Tozy highlights that Moroccan religious institutions

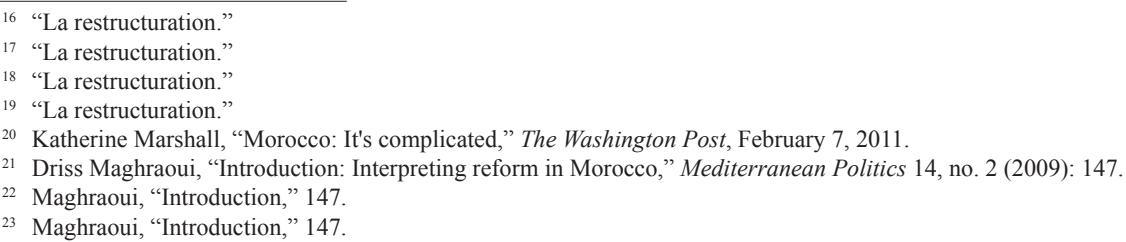


no longer have a monopoly on the production or dissemination of religion. In fact, there has been an internationalization of religious discourses, ${ }^{24}$ where state religious values are not necessarily a carbon copy of society's values. Tozy adds that a uniformly calibrated speech formulated by the state cannot meet this new demand of religiosity that is diverse, intense and both normative and intellectual. The state cannot accommodate all these fragmented requests, especially since it is not the only player in the religious field; there must be some kind of flexibility to address this diversity of offerings..$^{25}$

Yet, Moroccan Islam "is the example of an internal policy that can be exported.... Around the concept of 'spiritual security' it was necessary to erect a bulwark against fundamentalism and stand up in the same time to Wahhabism and Shiism." ${ }^{26}$ Indeed, the Moroccan Islamic model has become a vision that the monarchy does intend to share; Europeans and other Africans have expressed their desire to send their imams to Morocco to learn its basics. The international community seems very curious about "this Moroccan model, based on a bureaucratization of the religious field. This involved, of course, the prestigious rank of the Monarch." 27

\section{Openness to the Moderate Islam-oriented PJD}

The PJD arose out of a radical Islamic group founded in 1969 by Abdelkrim Mutii and Kamel Ibrahim, known as Al-Shabiba al-Islamiya (the Islamic Youth), which was the first Islamist movement in Morocco to use violence as a political weapon - in this case, against Moroccan leftists and secularists in the 1970s. For that reason, "it was tolerated - some say encouraged - by the Makhzen." ${ }^{28}$ At that time, Al-Shabiba al-Islamiya was also rejecting the existing political order and demanding radical change. Yet "a sizeable number of its members eventually realized that their strategy was not leading anywhere." ${ }^{29}$ In fact, the movement lost most of its core membership and structure after 1981 due to government repression and divergent visions on how to achieve its goals. A moderate Islamist group (Movement for Unity and Reform; MUR) led by Abdelilah Benkirane (now Morocco's head of the government) emerged from Al-Shabiba, distancing itself from that group's confrontational approach to the monarchy. It acknowledged King Hassan II as Commander of the Faithful and turned its focus on the secularists (communists, socialists, feminists, and Westernized elite). With the authorization and encouragement of then-Minister of the Interior Driss Basri, the MUR eventually joined the Mouvement populaire démocratique et constitutionnel (MPDC), which had been founded in the late 1960s by Abdelkrim Al Khatib but by the early 1980s was functioning as an empty shell.

The MPDC, strong now, changed its name to the PJD in 1998. The party was content to remain in opposition for some time, believing that the political context was not conducive to joining the government. Learning from the Algerian events of 1990, "the PJD adopted a softly-softly approach, eschewing radical rhetoric and putting only limited numbers of

\footnotetext{
24 "La restructuration."

25 "La restructuration."

26 Mohamed Tozy, "Mohamed Tozy: Le roi du Maroc gère le temps long, celui de la stratégie," interview by Youssef Aït Akdim, Jeune Afrique, August 5, 2014

27 Tozy, "Mohamed Tozy."

28 Ana Belen Soage, "Political Islam in Morocco: Is there an 'exception marocaine'?" Middle East Review of International Affairs 17, no. 3 (Fall 2013): 3. 
candidates up for election." ${ }^{30}$ To ensure its existence on the political map, the PJD shifted from questioning the legitimacy of king's political and religious authority to fervently defending the monarchy's symbols. Nonetheless, "by agreeing to play by the rules of the game and accepting the king as... Commander of the Faithful, the PJD is beholden to the same constraints as other parties." 31

In 1997, the party won eight seats in the parliamentary election. In 2002, it won 42 out of 325 seats, winning most of the districts where it fielded candidates. In September 2007, Morocco organized nationwide, direct elections, which most analysts ${ }^{32}$ predicted would be won by the Islamist PJD. The political context was encouraging since the king himself had begun a few years earlier to send out signals concerning a range of socio-political reforms. He pushed for reforming the Family Code, expanding human rights, and for more freedom of expression. However, the PJD's anticipated victory did not materialize, as it garnered only about $37 \%$ of the vote. The reasons for the defeat are not clear. Was it because Moroccans were afraid of the PJD's radical ideas (no more music concerts and controlling foreign tourism)? Or was it because the PJD could not reach the tribal and rural milieux, where people are more loyal to traditional parties and do not vote for new ideological ideas? Regardless of the loss, the PJD

\begin{abstract}
had in fact emerged as the most popular party - winning more votes than any other party, but was deprived of becoming the largest party by the mechanics of the electoral system[,] which had clearly favored the Istiqlal party [as it] had concentrated the votes it had received more effectively in the electoral districts than had the PJD." ${ }^{\prime 3}$
\end{abstract}

The PJD was then forced to stay out of any governing coalitions and continued to situate itself in the opposition by maintaining a degree of distance from all political parties and the monarchy's advisors.

In November 2011, 45.4\% of Moroccans voted to elect parliamentary members in the wake of the new constitutional reforms. The PJD won 107 seats out of 395, after waiting more than 15 years in the opposition ranks. In the era of the Arab Spring, the Islam-oriented PJD (which some call "the most internally democratic" 34 party in Morocco and one that "benefits greatly from its uncorrupt image" ${ }^{35}$ ) used the country's political and social discontent evidenced by the February $20^{\text {th }}$ Movement ${ }^{36}$ to position itself as an alternative to traditional political parties.

\title{
4. Pragmatic Cohabitation between the Monarchy and the PJD
}

While Head of Government Benkirane publicly supports the monarchy, the latter has distanced itself from the management of public affairs to avoid the consequences of failure and accountability. The palace's strategy is "to deny Benkirane the right to co-decision over the strategic affairs of the state while allowing him to [make] unpopular decisions." ${ }^{37}$

\footnotetext{
30 Michael J. Willis, "Islamism, Democratization and Disillusionment: Morocco's Legislative Elections of 2007" (research paper no. 1, St Antony's College, Oxford University, 2008), 3.

31 James Liddell, "Notables, Clientelism and the Politics of Change in Morocco," The Journal of North African Studies 15, no. 3 (2010): 328

32 Liddell, "Notables," 315

33 Willis, "Islamism," 8.

34 Liddell, "Notables," 321

35 Liddell, "Notables," 321

36 The February $20^{\text {th }}$ Movement is a movement led by Moroccan youth from different ideological affiliations in response to the 2011 Arab Spring.

37 Boukhars, "Morocco's Islamists," 4.
} 


\subsection{Benkirane's loyalty to the monarchy}

Since forming the government, the PJD has become convinced that its interests are to protect the monarchy, the only guarantor of unifying the country around the Moroccan model of Islam. Although the head of the government theoretically has, by the new constitution, more autonomy than his predecessors, it is the king who still has the last word. Pragmatic as he is, Benkirane has been careful thus far not to challenge the Mohammed VI's supremacy, preferring to maintain good relations with the monarch..$^{38}$ Indeed, political participation in Morocco depends on accepting that it is the monarchy that shapes big policies. The PJD has so far remained "deferent to the monarchy and to its executive primacy." ${ }^{39}$ Yet, even if the PJD as a whole restrains from criticizing the king himself, "Benkirane frequently lashes out at the subterfuge of what he calls the 'ghosts' and 'crocodiles' of the invisible but powerful 'Makhzenian' force." ${ }^{\prime 0}$

The PJD's leaders "prefer to be inside institutions and trying to [effect] change rather than being [kept] outside and... unable to see any of their most preferred policies implemented." ${ }^{41}$ For this reason, even if the Islamist Benkirane sometimes finds the monarchy's practices in contradiction with his own Islamic ideology, he refrains from saying so in public. In an interview with French media, Benkirane explains: "Initially, we had an absolute executive monarchy...and today we are moving towards a parliamentary monarchy." 42 In a second French interview, while at the World Forum for Democracy in Strasbourg, Benkirane insists that "democracy is advancing slowly but surely.... We are in the process of taking small, but decisive steps." ${ }^{43}$ Benkirane must maintain peace so that he will be better able to keep the king's support if and when other parties caution the monarchy and Moroccan citizens about the risk of allowing an Islamist party to govern.

\subsection{Control and criticism of the 'Islamist government' by the monarchy}

Since 2013, there has been a radical shift in King Mohammed VI's speeches, where they are more focused on specific topics and interspersed with explicit criticism of Moroccan authorities' performances both inside and outside the government. In Mohammed VI's early years as king, he refrained from such comments, but now he does not hide his disapproval of certain actions and initiatives led by the Islam-oriented PJD. In one of his speeches, the king praised the previous government and criticized the current one. ${ }^{44}$ In another speech, he said "the current government should have invested in the education and training sectors" instead of engaging the country in educational programs that ultimately failed. ${ }^{45}$

${ }^{38}$ Dominique Lagarde, “Maroc: un an après, Benkirane reste un Premier ministre populaire," L'Express, January 23, 2013.

39 Emanuela Dalmasso and Francesco Cavatorta, "Political Islam in Morocco: Negotiating the liberal space post 2003" (paper prepared for the ECPR Joint Sessions Workshop 1, 'Globalisation, Secularisation and Religion - Different States, Same Trajectories?, St. Gallen, Switzerland, April 2011), 7.

40 Boukhars, "Morocco's Islamists," 3.

${ }^{41}$ Boukhars, "Morocco's Islamists," 15.

42 Le Monde, "Abdelilah Benkirane," Internationales video, 45:12, February 24, 2013, http://www.tv5monde.com/cms/chainefrancophone/Revoir-nos-emissions/Internationales/Episodes/p-24534-Abdelilah-Benkirane.htm

${ }^{43}$ Abdelilah Benkirane, "Benkirane: Democracy in Morocco advancing slowly but surely," October 10, 2012, http:// moroccoonthemove.com/2012/10/10/Benkirane-democracy-in-morocco-advancing-slowly-but-surely-middle-east-online/\#sthash. Oju2H05S.dpbs.

${ }^{44}$ Mohammed Alaoui, "Discours à la Nation du 30 Juillet 2014 par sa Majesté le Roi,” [July 30, 2014 Throne Speech] YouTube video, 30:27, July 30, 2013, https://www.youtube.com/watch?v=ZbLYQQrhrDk.

${ }^{45}$ Mohammed Alaoui, "Discours royal le 20 août 2013 - 60ème anniversaire de la Révolution du roi et du Peuple," [August 20, 2013 Throne Speech on the 60th Anniversary of the King's and People's Revolution] YouTube video, 14:54, August 20, 2013, https:// www.youtube.com/watch?v=fp-jRMnMWFg. 
If we carefully analyze the king's speeches, the message is that the current government cannot easily erase all that has been done by previous governments, especially what has been initiated by the monarchy. When it comes to strategies and broad reforms, the government, Islamist or not, must run with what has been concocted by the shadow government (the king's advisors). The monarchy claims the power to direct, evaluate, and adjust all political projects, and publicly if necessary. Mohammed VI's criticism of the PJD emphasizes the regime's assertion that he is the guarantor of stability and continuity, which cannot be achieved without responsibility and accountability from the government. This shift in tone is also associated with the will to highlight the monarchy's legitimacy in a pragmatic world dominated by utilitarian interests.

It is true that some of the forces resisting change do not hide their desire to see the Moroccan regime oust the Islamists from government or even exclude them from political life, but the monarchy is wise enough not to fall into the trap of weakening moderate Islamists and thus strengthening their extremist wings. The monarchy is claiming to seek a balanced relationship with the Islamist movement, understanding that exclusion will not work. The complexity of Morocco's political and social contexts makes it difficult to the PJD's growing intellectual and conceptual propositional ideas related to their Islamic ideology, regardless of their effectiveness, because they represent an important percentage of the population.

\section{Challenges for the PJD}

After a year and a half, the Istiqlal withdrew from the government coalition in a game some feel was initiated by a number of the king's counselors to weaken the PJD's popularity. Instead of providing appropriate conditions to help overcome the economic crisis and preserve stability, the Makhzen appeared to be blocking the PJD from initiating real change by highlighting their lack of experience in public governance. And when the crisis intensified, the Makhzen appeared to ease the situation by proposing partial reforms, but they were ultimately inapt.

Concerning individual freedoms, Benkirane maintains that the government rejects "the idea of interfering in people's lives. People need to first obtain their [primary] rights. ${ }^{~} 6$ Regarding detainment and torture, Benkirane insists that Morocco has no political prisoners. He added, "torture did occur in Morocco, and it dates back to 30 or 40 years ago. Now it's over... Our services and the Minister of Justice say that it is over." ${ }^{47}$ Nonetheless, in its 2013 report, the Moroccan Association for Human Rights refuted Benkirane's statements, estimating the number of political prisoners at 217 in 2012. Regarding social reforms, Benkirane states that "opportunism, cronyism, and bribery are no longer seen as criteria for employment in Morocco. Perceptions are being corrected, and normal approaches based on competence and merit, integrity and transparency are being pursued." ${ }^{\prime 4}$ Although just after his appointment he stated that his government's priority is to fight corruption and authoritarianism, Benkirane admitted in an interview with Al Jazeera that the government cannot totally eradicate political cronyism and corruption. "We cannot afford to light a candle and look into all the intricacies of the state regarding those who have engaged in corruption, because it would be a crime against the nation." 49

\footnotetext{
46 Le Monde, “Abdelilah Benkirane.”

47 Le Monde, "Abdelilah Benkirane."

48 Le Monde, "Abdelilah Benkirane."

49 Al Jazeera, "Bila Hodoud," YouTube video, 49:03, August 2, 2012, https://www.youtube.com/watch?v=kHSEZWD69uM.
} 
In fact, with no majority to govern alone, the PJD has been forced to negotiate alliances with parties from different ideological affiliations that lost credibility decades ago in the eyes of Moroccans, when they failed to fulfill their promises of raising the standard of living. Further, because of the international situation, there has been a decrease of foreign inflows from Moroccans abroad, and tourism revenues have not been enough to bridge the trade deficit. ${ }^{50}$ Helpless at the economic level between 2011 and 2014, the PJD seemed to focus on the social issues. However, except for few symbolic measures, its electoral promises to fight corruption and unemployment have not translated into action. Nonetheless, the drop in oil prices and a good 2015 agricultural year, thanks to abundant rain, may help Benkirane's government to implement some of its promises by the end of December.

Under the above constraints, the PJD will not be able keep all of its campaign promises, especially since it has inherited heavy issues such as a public deficit, housing problems, health and social security problems, and huge educational demands. Room to maneuver is particularly limited since the new constitution preserves the monarch's political, religious, and legal supreme powers. The shadow government continues to intervene in decision making, blocking the government from managing important and strategic economic and political files. Hence, the PJD runs the risk of disappointing its trusting grassroots supporters because real reforms are not being implemented. To assume governmental responsibility under difficult circumstances (international economic crises, the post-Arab Spring era, and the absence of national good governance and accountability) without real authority was a challenging decision for the PJD.

\section{The Need for an Islamic Political Secularism}

Josep Dieste states that "in spite of its political participation, the PJD defends an Islamist project that proposes the purification of Moroccan society through an application of the shariaa." ${ }_{51}$ This may be true for some radical voices in the PJD, but other leading figures in the party think that the call for an Islamist government to apply the shariaa is unrealistic in an open society like Morocco, and further, not an interpretation that they support. In 2005, Saâdeddine Al-Othmani, a senior leader in the PJD and a former minister of foreign affairs, compared the party to "Christian Democratic parties in Europe that base their platforms upon the principles of Christian faith although their platforms may be civil in nature." ${ }^{52} \mathrm{Al}-$ Othmani thinks his party must make decisions according to civil political realities, but must continue to view things through an Islamic lens.

The PJD is diligently trying to rationalize itself while keeping the banner of religion hoisted. This moderate Islam-oriented party is being called on now more than ever to propose a new interpretation of the Islamic texts, one compatible with modern views. It is true that the PJD's reference is Islam, but discussions about a specific type of Islamic political secularism must start to take place among party thinkers. Lessons can be learned from Turkey (the most obvious model of combining Islam and democracy) and even from France and the United States. Of course, Turkey has a legacy of secularism, but an Islamic political secularism in Morocco that respects citizens' political, social, and cultural choices would help create a

50 “Morocco's Trade Deficit Rises," Reuters, September 17, 2012.

51 Josep L-M. Dieste, "Demonstrating Islam: the Conflict of Text and the Mudawwana Reform in Morocco," The Muslim World 99, no. 1 (2009): 141.

52 Amr Hamzawy, "Interview with Saad Eddin Al Othmani, leader of Morocco's Party of Justice and Development," Carnegie Endowment for International Peace, December 20, 2005, 1. 
political environment that engages different ideas and avoids superfluous clashes between secularists and Islamists. Such Islamic political secularism must be understood as principles that are crucial to the functioning of society in a democratic way and would not stop Moroccans from practicing their religion.

There is no one kind of secularism, and secularism in Morocco must not be seen as an attempt to take religion away from the people. Ahmet Kuru notes that secular states with legal systems free from religious control pursue substantially different policies toward religion. He explains that "in France and Turkey the dominant ideology is 'assertive secularism,' which aims to exclude religion from the public sphere, while in the U.S., it is "passive secularism," which tolerates public visibility of religion." ${ }^{53}$ For example, the French and Turkish states have banned student headscarves in public schools, whereas the U.S. allows students to wear religious symbols and attire. In considering similar issues, the PJD must activate the old scholarly consensus and the Ijtihad ${ }^{54}$ process to interpret the Hadith ${ }^{55}$ and other Islamic texts to find solutions to current issues in modern Moroccan society. Such decisions would be about a new interpretation of the Koran and other religious sources of legislation - not rejecting Western ideals related to democracy, human rights, equality, and freedom, but also not contradicting Islamic principles. In this sense, the Koran and other religious texts can be interpreted commensurately with what is happening in the twenty-first century. Morocco

should come up with a model of governance that is harmonious with the universal principles and not discordant with the Islamic teachings; a model that does not disregard the successful experience of democracy in some western countries nor... is a simple facsimile of the Islamic Empire's legislations that were applied centuries ago. ${ }^{56}$

Islamic political secularism means interpretations that must parallel the evolution of modern society in areas such as democratization, women's rights, freedom of expression, and minority rights; an Islam able to disseminate religious knowledge that combines authenticity and modernity. These kinds of interpretations will help find answers to many issues of concern that Moroccan society may face, which will guide the future generations within a pluralistic society. On a 2011 visit to Tunis, then-Turkish Prime Minsiter Tayyip Erdogan said, "A Muslim can govern a secular state in a successful way." ${ }^{57} \mathrm{He}$ was paraphrased as saying that Tunisia should have nothing to fear from the influence of Islam in politics: "[t]he most important thing of all and Tunisia will prove this; Islam and democracy can exist side by side. ${ }^{58}$ Erdogan does distinguish, however, between secularism at the individual and the state levels. For him, it "is not secularism in the Anglo Saxon or Western sense, a person is not secular, the state is secular." ${ }^{59}$

Between the 1970s and late 1990s, Moroccan Islamists and secular leftists struggled to find common ground due to their profound ideological differences. Since the 2000s, the two groups have moved beyond ideology and have been confronting each other on concrete political issues such as democracy, accountability, human rights, and development. These

\footnotetext{
53 Ahmet T. Kuru, "Passive and Assertive Secularism: Historical Conditions, Ideological Struggles, and State Policies toward Religion," World Politics 59, no. 4 (July 2007): 1.

${ }_{54}$ In Islamic law, Ijtihad is an independent interpretation of problems not precisely covered by the Koran.

55 The Hadith are the collections of the reports of the teachings, deeds, and sayings of the Islamic prophet Mohammed.

56 Zouhair El Aouni, "Morocco: A Case Study for Political Schizophrenia," Tariq Ramadan, May 6, 2014, http://tariqramadan. com/english/2014/05/06/morocco-a-case-study-for-political-schizophrenia-by-zouhair-el-aouni/.

57 Sylvia Westall, "Islam can exist with democracy, Turkish PM Erdogan tells Tunisians," Reuters, September 15, 2011, http:// blogs.reuters.com/faithworld/2011/09/15/islam-can-exist-with-democracy-says-turkish-pm-erdogan/.

58 Westall, "Islam can exist with democracy."

59 Westall, "Islam can exist with democracy."
} 
meetings have led to dialogue and cooperation between Islamists and secular-leftists due to a convergence of interests and opinions. In the last few years, the PJD has found it easier than when it was in opposition to achieve alliances with non-Islam-oriented political parties and secular civil society. Indeed, "it is the relationship with the Monarchy that determines the relationship with other political and social movements." ${ }^{.60}$

The 2011 mobilizations during the Arab Spring provided young Moroccan, secular, and Islamist militants the opportunity to struggle together, share the public space, and impart new visions to the old guard in their respective camps. ${ }^{61}$ This situation was an example of mutual compromise because the real problem is less related to religion and other secular ideologies than it is to social and economic problems. The outcome is another example that when religion is not involved, common ground can be found between different groups with different ideological affiliations.

The PJD has been working in a difficult environment since it came to power in late 2011. "Complicating matters for the PJD is that the combination of opposition obstructionism, bureaucratic contestation, elite intrigue and media hostility has bogged down the party's efforts to shape public policy and legislation." ${ }^{62}$ These blockages led to several months of political crisis in 2013, which resulted in the Istiqlal party's withdrawal from the government. Furthermore, the USFP continues to resent the Islamists' monopolization and use of the religion card, and accuses Benkirane of renouncing his constitutional power. Adding more fuel to the fire, in April 2015 Hamid Chabat, Secretary General of the Istiqlal Party, leaked the news of what Moroccans now call "the government couple." Married Islamist Habib Choubani, minister delegate in charge of Relations between Parliament and Civil Society proposed to divorced Islamist Soumia Benkhaldoun, Minister Delegate to the Minister of Higher Education, Scientific Research and Executive training. Although Islam accepts polygamy, the case has stirred controversy both in Morocco and abroad because such marital arrangements go against what many Moroccan citizens believe today. Benkirane recently expressed his discontent with the romance, saying the relationship has tarnished the image of the PJD and presented a golden opportunity for political rivals to sharply criticize the Islamist party. ${ }^{63}$

A political secularism that respects the Moroccan Islam model would still allow nonreligious ideals to be respected and non-Islamic groups to be involved in political debates. This type of secularism, however, must maintain the role of the monarch as the Commander of the Faithful, presenting him as the only figure who can reconcile the political and the religious and counter the rising power of Islamist groups, and more importantly, stop radicalism. In a society where almost the entire population identifies as Muslim, it would indeed benefit the PJD to stop using religion to promote its political agenda. The PJD must explicitly define the fine line between religion and politics in Morocco, because neither political successes nor failures should be justified by religion or piety ${ }^{64}$ Islamist or otherwise, Moroccan political parties must deal with issues concerning the economy, education, unemployment, and human rights, and not interfere with the Commander of the Faithful in the religious field.

60 Dalmasso and Cavatorta, "Political Islam in Morocco," 16.

${ }^{61}$ Jean-François Bayart, "Etre laïque en terre d'islam," Le Monde, November 28, 2011.

62 Boukhars, "Morocco's Islamists," 4.

63 Akhbar Alyaoum, "Benkirane breaks his silence about the case of Choubani and Benkhaldounm," Alyaoum 24, April 23, 2015, 1, http://www.alyaoum 24.com/pdf $\%$ d $8 \% a 7 \% d 9 \% 84 \% d 8 \%$ b9\%d8\%af\%d $\% \% a f-1658$.

64 "La restructuration." 


\section{Conclusion}

The arrival of Islamists to power has helped ease tensions in the streets and reinforced the image of a stable Moroccan system within a difficult regional Arab environment. Today, the moderate Islam-oriented PJD is attempting to serve Moroccan society and alter the political game from within. The party is convinced that it should protect the monarchy because the king is the only guarantor of national unification. However, it has been difficult for the PJD's leaders in the government to take real political, economic and social action, because the departments and authorities within the Moroccan political system are so intertwined. In fact, it is complicated for any official without the backing of the monarchy to make substantial decisions. The PJD continues to believe, however, in achieving change by parliamentary means and by participating in sharing executive power. Therefore, rather than adopting rapid and radical transition, it sees a gradual transition to real democracy through reforms initiated by the monarchy.

Moroccan politics today is about a pragmatic cohabitation between the king and the Islam-oriented PJD, where the country's interests and stability are emphasized. Yet, major strategic plans will continue to be set largely by the monarchy, despite some steps towards devolving more power to the Head of Government. It is true that the PJD has found common ground with the monarchy on general issues such as human rights and development, but it must also have the courage to confront corruption and clientelism in the political elite, as those issues are blocking real change. The PJD's main challenge, however, lies in ensuring efficient governance of public affairs now and in the future. It is true that the PJD was voted in to avoid the scenarios of Algeria and Egypt happening in Morocco, but the Islamist party may yet lose credibility since it has been thus far unable to fulfill its promises, especially in job creation and the fight against corruption.

To ease tensions between the Islamists and other political actors (the monarchy, the Makhzen, other political parties and secular associations), the PJD feels it must adopt a type of Islamic political secularism that respects the Moroccan Islam model. As a matter of fact, this secularism exists implicitly but is dominated by a political Islamism in which the king and Islamist parties play different roles. To promote the moderate Islamism that most in Moroccan society support, and to counter any other interpretation of Islam that may be claimed by extremists, Morocco needs to promote a type of political secularism that would preserve the monarch's title as Commander of the Faithful yet open society to modernism. This type of political secularism would also allow the PJD to gain more power by opening itself up to new ideas and actors; "the party's base... is still largely limited to teachers and civil servants, and it still badly lacks support among the intelligentsia and business elites." ${ }_{65}$ Such a move would put the PJD in a strong position and begin to allow the implementation, even partially, of its political agenda.

\section{Bibliography}

Alyaoum, Akhbar. "Benkirane breaks his silence about the case of Choubani and Benkhaldoun." Alyaoum 24, April 23, 2015. http://www.alyaoum24.com/pdf/\%d8\%a7\%d9\%84\%d8\%b9\%d8\%af\%d8\%af-1658.

Arieff, Alexis. Morocco: Current issues (CRS Report No. RL21579) Washington, DC: Congressional Research Service, 2013. http://www.fas.org/sgp/crs/row/RS21579.pdf.

\footnotetext{
${ }^{65}$ Liddell, "Notables," 322.
} 
Bayart, Jean-François. “Etre laïque en terre d'islam.” Le Monde, November 28, 2011.

Benkirane, Abdelilah. "Benkirane: Democracy in Morocco advancing slowly but surely." October 10, 2012. http:// moroccoonthemove.com/2012/10/10/Benkirane-democracy-in-morocco-advancing-slowly-but-surely-middleeast-online/\#sthash.Oju2H05S.dpbs.

Boukhars, Anouar. "Morocco's Islamists: Bucking the trend?” FRIDE Policy Brief No. 182, June 2014. http://fride. org/download/PB_182_Morocco_Islamists.pdf.

Daadaoui, Mohamed. "Rituals of Power and Political Parties in Morocco: Limited elections as positional strategies." Middle Eastern Studies 46, no. 2 (2010): 195-219.

Dalmasso, Emanuela and Francesco Cavatorta. "Political Islam in Morocco: Negotiating the liberal space post 2003." Paper prepared for the ECPR Joint Sessions Workshop, 'Globalisation, Secularisation and Religion Different States, Same Trajectories?’ St. Gallen, Switzerland, April 2011. http://doras.dcu.ie/16302/1/1104.pdf.

Dieste, Josep L-M. "Demonstrating Islam: the Conflict of Text and the Mudawwana Reform in Morocco." The Muslim World 99, no. 1 (2009): 134-154.

El Aouni, Zouhair. "Morocco: A Case Study for Political Schizophrenia." Tariq Ramadan, May 6, 2014. http:// tariqramadan.com/english/2014/05/06/morocco-a-case-study-for-political-schizophrenia-by-zouhair-el-aouni/.

Hamzawy, Amr. "Interview with Saad Eddin Al Othmani, leader of Morocco's Party of Justice and Development." Carnegie Endowment for International Peace, December 20, 2005. http://carnegieendowment.org/2008/08/20/ interview-with-saad-eddin-al-othmani-leader-of-morocco-s-party-of-justice-and-development/fhr5.

Josep, L-M. Dieste. "Demonstrating Islam: the Conflict of Text and the Mudawwana Reform in Morocco." The Muslim World 99, no. 1 (2009): 134-54.

Kausch, Kristina. “The European Union and Political Reform in Morocco.” Mediterranean Politics 14, no. 2 (2009): 165-79.

Kuru, Ahmet T. "Passive and Assertive Secularism: Historical Conditions, Ideological Struggles, and State Policies toward Religion.” World Politics 59, no. 4 (July 2007): 568-94.

Lagarde, Dominique. “Maroc: un an après, Benkirane reste un Premier ministre populaire.” L'Express, January 23, 2013.

Liddell, James. "Notables, Clientelism and the Politics of Change in Morocco." The Journal of North African Studies 15, no. 3 (2010): 315-31.

Maghraoui, Driss. "Introduction: Interpreting reform in Morocco." Mediterranean Politics 14, no. 2 (2009): 143-49.

Marshall, Katherine. “Morocco: It’s complicated.” The Washington Post, February 7, 2011.

Monjib, Maâti. "The Democratization Process in Morocco: Progress, obstacles, and the impact of the IslamistSecularist divide.” Working Paper 5, The Saban Center for Middle East Policy at the Brookings Institute, 2011. http://www.brookings.edu/ /media/research/files/papers/2011/8/morocco\%20monjib/08_morocco_monjib.pdf.

Sallon, Hélène. "Mohamed VI offre au Maroc une révolution tranquille.” Le Monde, March 10, 2011.

Sater, James. "Parliamentary Elections and Authoritarian Rule in Morocco.” Middle East Journal 63, no. 3 (2009): 381-400.

Soage, Ana Belen. "Political Islam in Morocco: Is there an 'exception marocaine'?" Middle East Review of International Affairs 17, no. 3 (Fall 2013): 1-7.

Tozy, Mohamed. "Islamists, Technocrats, and the Palace." Journal of Democracy 19, no. 1 (2008): 34-41.

—_ "Mohamed Tozy : Le roi du Maroc gère le temps long, celui de la stratégie." By Youssef Aït Akdim. Jeune Afrique, August 5, 2014.

U.S. Department of State. 2011 Human Rights Reports: Morocco. http://www.state.gov/j/drl/rls/hrrpt/2011/nea/186440.htm.

Weastall, Sylvia. "Islam can exist with democracy, Turkish PM Erdogan tells Tunisians." Reuters, September 15, 2011. http://blogs.reuters.com/faithworld/2011/09/15/islam-can-exist-with-democracy-says-turkish-pmerdogan/.

Willis, J. Michael. "Islamism, Democratization and Disillusionment: Morocco's Legislative Elections of 2007." Research paper, St Antony's College, Oxford University, 2008. http://www.sant.ox.ac.uk/mec/morocco/ Islamism-Democratisation-Disillusionment.pdf. 